\title{
Translating and Transcending Textual Criticism
}

\author{
John Screnock | ORCID: 0000-0003-2965-9522 \\ University of Oxford, Oxford, UK \\ john.screnock@orinst.ox.ac.uk
}

On 14-15 May 2019, a group of scholars gathered to consider textual criticism and translation at the colloquium "Horizons in Textual Criticism: Translating and Transcending Textual Criticism."1 Oxford has a vibrant academic community of faculty and students studying ancient Hebrew and Jewish texts, who welcomed the conference enthusiastically. The new scholarship presented by speakers engendered rich and productive conversations. Four of the papers from that colloquium are presented in this volume of Textus. Also included is a paper in the same vein, delivered later in the year at Oxford's Seminar on Jewish History and Literature in the Graeco-Roman Period, written by a member of the Oxford community who participated in the colloquium.

Among other commonalities, each of the following articles demonstrates that textual criticism is entangled with a broad range of related disciplines and possible methodologies. These relationships are two-way streets: textual criticism depends on good knowledge of other areas, but textual criticism also impacts other areas. The articles also highlight how disordered, tangled, and rich the translational evidence is. Izaak de Hulster and Tuukka Kauhanen show that archaeology, language, and history belong in textual criticism alongside minute analysis of textual witnesses. Vladimir Olivero argues that the Greek translation of Hebrew Prov 30:15-16 alludes to Hesiod's Theogony; the nature of the translation illustrates the hybrid character of diaspora Judaism that contextualizes the Septuagint. Alison Salvesen pushes for a new appreciation of Symmachus, showing more of the contours of his translation of Job and their value for areas like Jewish exegesis. Stefan Schorch argues that the variation

1 I am grateful to the many organizations and funders that supported the colloquium: the John Fell oup Fund, The Oxford Research Centre in the Humanities (товсн), the Centre for Hebrew and Jewish Studies, the Kennicott Fund, the Pusey and Ellerton Fund, and the Arts and Humanities Research Council (grant number AH/soo1743/1). I would also like to thank Charlotte Screnock for her invaluable assistance in editing and proofing the following articles. 
we see in the Samaritan Aramaic translations goes back to earlier evidence of variation in Hebrew witnesses. Drawing on translation analysis and textual criticism, he critiques the notion of the Ur-translation. Like Schorch, though departing from a different methodological framework, Pablo Torijano makes a compelling case for the value of versional evidence, which is often ignored or unknown. Hidden in the Lucianic and Old Latin witnesses-in the methodological margins for most biblical scholars - there is evidence that critically impacts our understanding of Hebrew language, the text, and the history of Israel.

Another striking feature of the textual evidence, lying just beneath the surface in each of these essays, has to do with reading texts. Judging by my own experience, and by the extent to which secondary scholarship has discussed interpretation of individual texts, I think it is fair to say that most ancient Jewish texts are complex and full. All kinds of depths can be explored. I mean this, in the first place, in terms of just one instantiation of any particular textmost often (in biblical scholarship) the Leningrad Codex, as a representative of the Masoretic Text (MT). In other words, even before we bring in the multifaceted text-critical evidence of the sort explored in the following articles, reading a text is a complicated matter. How much more so when we add the richness and complexity that we ought to consider, by reading the different witnesses together as a messy jumble of testimony to the text. This of course involves reading the text(s) in all the available witnesses, but also some specific intentional stances: pursuing interpretations of individual witnesses seriously, without recourse to or interference from other witnesses; reading the witnesses as intertexts to one another; and reading along various diachronic, historical, literary, and religious considerations.

I offer here one brief illustration: the variant texts of Ps 49:13a and their implications for reading the entire psalm.

4QPsc , LXx, Peshitta2 ואדם ביקר בל יבין, "the person of stature cannot understand"

MT "וֹאָדָם בִּיקָר בַּל יָלִין abide"

2 I leave aside the question of Peshitta Psalms' relationship to the мт and Septuagint. The Peshitta's evidence here could be taken in a number of ways, only one of which has it independently testifying to this reading; it may differ from мт because of translational phenomena, or it may not independently witness the reading because the translation has an eye on the Greek all along. See Ignacio Carbajosa, The Character of the Syriac Version of Psalms: A Study of Psalms 9o-150 in the Peshitta, Monographs of the Peshitta Institute 17 (Leiden: Brill, 2008). 
There are a number of interesting ways to account for the variant, יבין versus ילין. Whatever the cause, what concerns me here is the interpretation of the text(s). This wisdom psalm considers the question of whether the wealthy and powerful should be feared (cf. v. 6). ${ }^{3}$ A number of principles are articulated, revolving around the theme that death comes to all people; ${ }^{4}$ the principle in v. 13 stands out, given its affinities with v. $21 .{ }^{5}$ Looking solely at one of the witnesses containing the first reading $-4 \mathrm{QPs}^{\mathrm{c}}$, for example, with gaps filled in judiciously using the other witnesses 6 - the exact interpretation could go in a number of directions. What exactly is an אדם ביקר (literally, "a man in honor")? ${ }^{7}$ Probably someone who is regarded highly by others (my "person of stature"; or, more pejoratively along the lines of NRsv's translation of יקר as "pomp," a "pompous person"); given the context of earlier verses this high regard results from the individual's wealth and power, not their character. This person is one of the others of the psalm, one of the people whom the text's audience is meant to be learning not to fear. Does the yiqtol verb יבין, read in context, entail future tense ("they will not understand"), habitual aspect ("they do not understand"), possibility ("they might not understand"), or ability ("they cannot understand")? All these readings are possible, though habitual aspect and ability are most likely in my view. Most important is the question of how this statement addresses the overriding concern of the psalm. Is the point simply that these others lack understanding (interpreting the yiqtol as habitual and, as such, monovalent, "they do not understand"), and so should not be feared? Or is the point specifically that they do not understand the main principle that death comes to all (as in the preceding vv. 10-12): "the person of stature does not/cannot understand this principle"? In either case, it is remarkable that the psalm puts emphasis on knowledge and wisdom, in keeping with the call to wisdom in vv. $2-5$, whereas the main body

3 John Goldingay, Psalms, Volume 2: Psalms 42-89 (Grand Rapids, MI: Baker Academic, 2006), 143; Peter Craigie, Psalms 1-50 (Nashville: Thomas Nelson, 2004), 358-359; Nancy DeClaisséWalford, Rolf A. Jacobson, and Beth LaNeel Tanner, The Book of Psalms (Grand Rapids, MI: Eerdmans, 2014), 439.

4 Craigie, Psalms 1-50, 359-36o.

5 Jan P. Fokkelman, Major Poems of the Hebrew Bible: At the Interface of Prosody and Structural Analysis. Volume III: The Remaining 65 Psalms (Assen:Van Gorcum, 2003), 83; Goldingay, Psalms 42-89, 143; DeClaissé-Walford et al., Psalms, 439-440.

6 See John Screnock, "A Reading of Psalm 104:1-13 according to the Text Contained in 4QPsalms ," RevQ 33 (2021).

7 Though it is syntactically possible, I find it unlikely that the prepositional phrase modifies the verb יבין; in the case of the text with ילין, however, it is easier to read the prepositional phrase as modifying the verb (see below). 
of the psalm (vv. 6-20) focuses on the inevitability of death. The (nearly) verbatim repetition of v. 13 in v. 21 drives home the importance of right knowledge and puts the entire line of thought in vv. 6-21 in a clear wisdom framework.

Reading the text as presented in the Leningrad Codex (representing мт), we again encounter various possibilities. The prepositional phrase modify the noun ("person of stature"), but alternatively it could modify the predicate: "a person cannot abide in prestige." In either case, the point seems to be the same: coming on the heels of vv. 10-12, people's [lack of] ability to control the time of their death is in view. Though לי"ן, "to abide," is semantically about lodging or passing the night somewhere, in this context it refers, metaphorically, to lodging among the living. The text continues its focus on the inescapability of death through v. 20. In v. 21, a clever play on v. 13 shifts focus back to the wisdom frame of vv. 2-5: "as for the person of stature- they cannot understand." As in the version of the text witnessed by $4 \mathrm{QPs}^{\mathrm{c}}$, $\mathrm{LXX}$, and the Peshitta, we have the same ambivalence about whether general understanding or specific understanding (of the inevitability of death principle) is in view. Coming, as it does, at the end of the poem, my sense is that both are entailed: the others of the psalm lack understanding, and as such they cannot understand the point being made. The reader is thereby put on notice: don't be one of them! Understand the wisdom presented here (cf. vv. 2-5).

Reading these two versions of the text-the text as contained in $4 \mathrm{QPs}^{\mathrm{c}}$, LXX, and the Peshitta, versus the text as contained in the MT-as intertexts means allowing the points of difference between them-the contrast created by putting the two side-by-side - to focus our interpretation on particular aspects of each text. Both address the question Why not fear powerful people?, and both point to humanity's lack of control over death as an answer. Both put this conversation, moreover, in the context of wisdom. The call to hear wisdom in vv. 2-5 and the gnomic character of the statements in vv. 6-21 put us generically in the realm of other literature that considers wisdom themes. Moreover, the final word of v. 21 shifts the audience's focus from the inevitability of death to the importance of understanding. The variation in v. 13, however, entails that the two versions accomplish this final element of wisdom framing in a different way. The version found in the Septuagint and $4 \mathrm{QPs}^{\mathrm{c}}$ emphasizes the importance of understanding via a clear refrain; breaking through the maxims about dying found throughout the psalm, the repeated statement in vv. 13 and 21 announces that understanding is crucial. Whereas the MT waits until the final moment to make this point, the Septuagint $/ 4 \mathrm{QPs}^{\mathrm{c}}$ flags it at important junctures in the middle and at the end of the discussion. And though the мт has a clear literary aesthetic (see below) in how it relates vv. 13 and 21, it 
must be said that the verbatim repetition found in the Septuagint $/ 4 \mathrm{QPs}^{\mathrm{c}}$ has poetic value as well.

When the MT is contrasted against the backdrop of the Septuagint $/ 4 \mathrm{QPs}^{\mathrm{c}}$ version, we place even higher emphasis on the slight change from ילין (v. 13) to יבין (v. 21). In contrast to the other version, MT's v. 13 keeps the reader's attention on the fact that the powerful and wealthy cannot control death; the focus is there for almost the entirety of the psalm, shifting to wisdom and understanding only in the final verse. When it does shift focus, it clearly alludes to v. 13, first

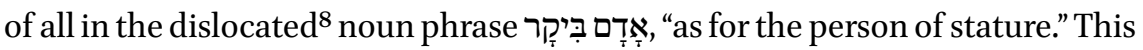
is topicalizing dislocation: ${ }^{9}$ the text essentially says, return your thought now to the person of stature we referred to earlier, in $v$. 13. Second, the M T's text subtly changes the words of v. 13 to make an altogether different point. Not only does the person of stature not have control over their existence, they do not even understand that this is the case. It is a difficult fact of life that we all die outside of our control; yet not to realize this is even worse. This statement, the coup de grace of the psalm, brings the audience back to the opening call of vv. 2-5 to heed the wisdom presented herein. It is a brilliant play on v. 13; as the most salient difference with our other version of the text, it comes to the fore even more when we read the two versions as intertexts.

Good textual criticism and translation analysis must engage in other methods and disciplines. At the same time, textual criticism and translation analysis can and should impact the wider field of biblical studies. Scholarship in biblical studies can only get better by incorporating textual criticism. To be sure, such incorporation has been done in scholarship past and present. However, I am not sure the perceived image of textual criticism has yet grown beyond technical, traditional analysis, rather than the many ways it can and does transform our other work. The articles in the following pages are exemplary in demonstrating the potential of textual criticism in this regard.

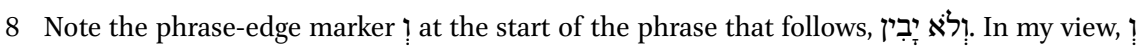
signals that we are to read the preceding noun phrase as outside of the syntax of the main clause.

9 Robert D. Holmstedt, "Critical at the Margins: Edge Constituents in Biblical Hebrew," KUSATU 17 (2014): 109-156. 